УДК 636.598.09:616.995.132

(C) 2018

Свстаф'єва В. О., доктор ветеринарних наук, професор,

Сресько В. I., аспірант

(науковий керівник - доктор ветеринарних наук, професор В. О. Свстаф'єва)

Полтавська державна аграрна академія

\title{
СЕЗОННА ДИНАМІКА КАПІЛЯРІОЗУ ГУСЕЙ
}

\section{Рецензент - доктор ветеринарних наук, професор А. А. Замазій}

У статті представлені результати досліджень показників інвазованості гусей збудником капіляріозу залежно від пори року в кліматичних умовах Полтавської області. Копроовоскопічно встановлено, щзо сезонна динаміка капіляріозу гусей характеризується підвищенням екстенсивності та інтенсивності інвазії у весняно-літній період року (до 54,55\% та 80,67 яєць/2) та їх зниженням $y$ зимовий період $(12,73 \%, 28,57$ яєць/2). Водночас за результатами гельмінтологічного розтину гусей максимальну кількість статевозрілих капілярій виявляли взимку та навесні (до 72,22\% та 37,48 екз./гол.), найменшу влітку (39,62\%, 11,86 екз./гол.).

Ключові слова: капіляріоз, гуси, екстенсивність, інтенсивність інвазї, сезонна динаміка.

Постановка проблеми. Птахівництво є однією з найбільш інтенсивних і динамічних галузей сільськогосподарського виробництва, яка дає можливість у короткі терміни значно збільшити виробництво дієтичних висококалорійних продуктів - м'яса та яєць, з метою забезпечення людей фізіологічно необхідною нормою харчування. Слід відзначити, що у м'ясному птахівництві для одержання 1 тонни м'яса потрібно у 12 разів менше часу, ніж у скотарстві, і у 8 разів менше, ніж у свинарстві.

Важливим резервом збільшення виробництва м'яса в Україні $\epsilon$ розвиток гусівництва як традиційної галузі в нашій державі. Відомо, що продукція гусівництва $€$ також цінним сировинним матеріалом для промисловості: пух і перо гусей $\epsilon$ найкращою сировиною для виготовлення перин, подушок, ковдр, теплих курток [2, 3, 4].

Паразитарні хвороби гусей $є$ однією з найсерйозніших перешкод у розвитку птахівництва, оскільки завдають значних збитків галузі. Основою комплексного захисту сільськогосподарської птиці від паразитарних захворювань, зокрема гельмінтозів, та їх прогнозування $\epsilon$ епізоотологічний моніторинг, основним завданням якого $\epsilon$ отримання і аналіз даних поширення збудників інвазій з урахуванням сезонних аспектів їх перебігу. Гельмінти, циркулюючи в організмі живителя, зумовлюють порушення цілісності його органів, механічно пошкоджуючи їх, що призводить до розвитку запальних та атрофічних процесів. Внаслідок цього молодняк відстає у рості й розвитку, знижується продуктивність гусей, іноді - птиця гине $[1,7,9]$.

Аналіз останніх досліджень і публікацій, у яких започатковано розв'язання проблеми. Повідомлення у вітчизняній та зарубіжній літературі свідчать про те, що капіляріоз $\epsilon$ поширеною нематодозною інвазією гусей у різних природо-кліматичних регіонах багатьох країн світу. Причому показники інвазованості водоплавної птиці збудником капіляріозу можуть сягати $100,0 \%[6,10]$.

Відомо, що кліматичні умови та температура навколишнього середовища як екологічного фактору впливає на біологічні особливості збудника, його життєздатність, а значить і на ймовірність зараження та ступінь інвазованості гусей. Так, Т. В. Маршалкіна та ін. (2013) [6] зазначають, що в умовах господарств степової зони України гуси максимально уражаються капіляріями у зимововесняний період року порівняно $з$ літньо-осіннім періодом. Водночас на території Брянської області вчені виявили вищі показники екстенсивності капіляріозної інвазії влітку та на початку осені. У листопаді ступінь інвазованості птиці знижувався, сягаючи мінімуму у лютому - березні [8].

Інші автори встановили, що у кліматичних умовах Північного Кавказу пік ураженості водоплавної птиці збудником капіляріозу припадає на літо (32,00-56,47 \%) зі зниженням показників екстенсивності інвазії у грудні (до $11,11 \%$ ) [5].

Отже, знання сезонних коливань зараженості птиці нематодами 3 урахуванням кліматичних умов досліджуваного регіону дасть змогу своєчасно й ефективно проводити заходи щодо боротьби та профілактики капіляріозу гусей.

У зв'язку з цим, метою роботи було вивчення сезонної динаміки капіляріозу гусей на території Полтавської області.

У завдання досліджень входило встановити екстенсивність та інтенсивність капіляріозної інвазії за результатами копроскопічних дослі- 


\section{ВЕТЕРИНАРНА МЕДИЦИНА}

джень залежно від пори року; дослідити сезонну динаміку за результатами гельмінтологічних розтинів птиці.

Матеріали і методи досліджень. Дослідження проводилися упродовж періоду 3 жовтня 2016 р. по вересень 2017 р. на базі наукової лабораторії кафедри паразитології та ветеринарносанітарної експертизи Полтавської державної аграрної академії. Показники сезонних коливань визначали кожної пори року в умовах СБК «Бір» Зіньківського району Полтавської області за результатами копроскопічних досліджень гусей віком від 7 місяців до 2 років, а також шляхом гельмінтологічного розтину їх кишечників.

Гельмінтоовоскопію проводили за методом В. Н. Трача, вираховували кількість яєць у 1 г посліду птиці (ЯГП). Всього досліджено 220 проб посліду та 284 кишечників (тонка, товста кишки).

Під час паразитологічного обстеження поголів'я основним показниками ураження гусей капіляріями були екстенсивність та інтенсивність інвазії (ЕI та II).

Результати досліджень. За результатами проведених паразитологічних досліджень встановлено, що показники екстенсивності та інтенсивності капіляріозної інвазії в гусей на території Полтавської області залежать від пори року. Причому, показники інвазованості водоплавної птиці капіляріями, виявлені за результатами зажиттєвої клопроовоскопічної діагностики та за результатами посмертної діагностики - гельмінтологічного розтину кишечників, значно відрізнялися (рис. 1, 2).

3'ясовано, що капіляріоз реєстрували впродовж року, однак максимальну ураженість капіляріями копроовоскопічно встановлювали у весняно-літній період року ЕI сягала 54,55 \%, за II до $80,67 \pm 5,29$ ЯГП.

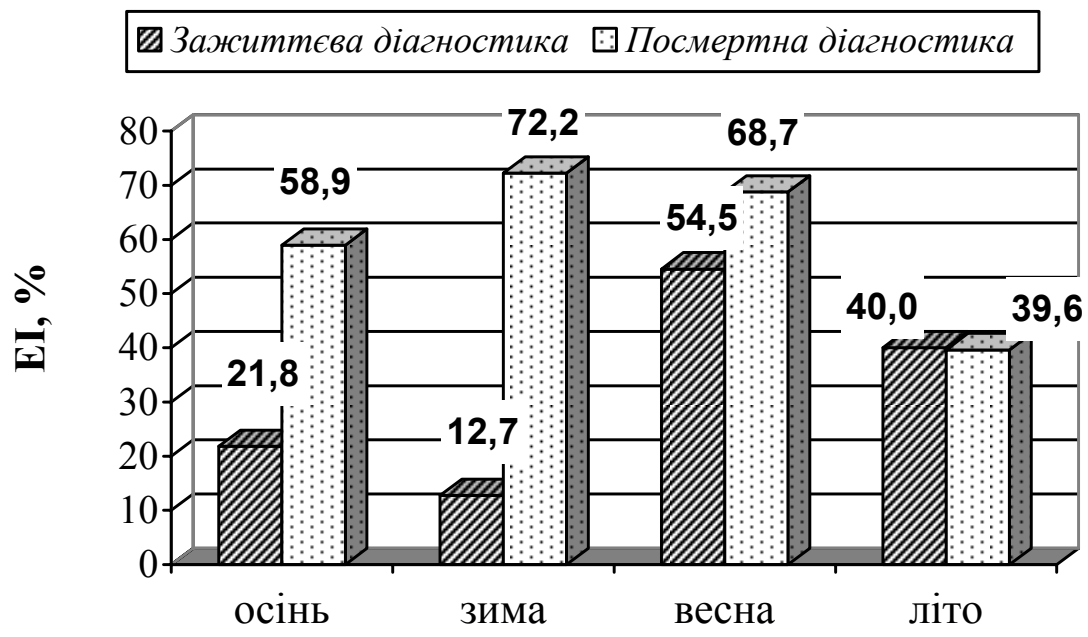

Рис. 1. Показники екстенсивності капіляріозної інвазї̈ залежно від пори року

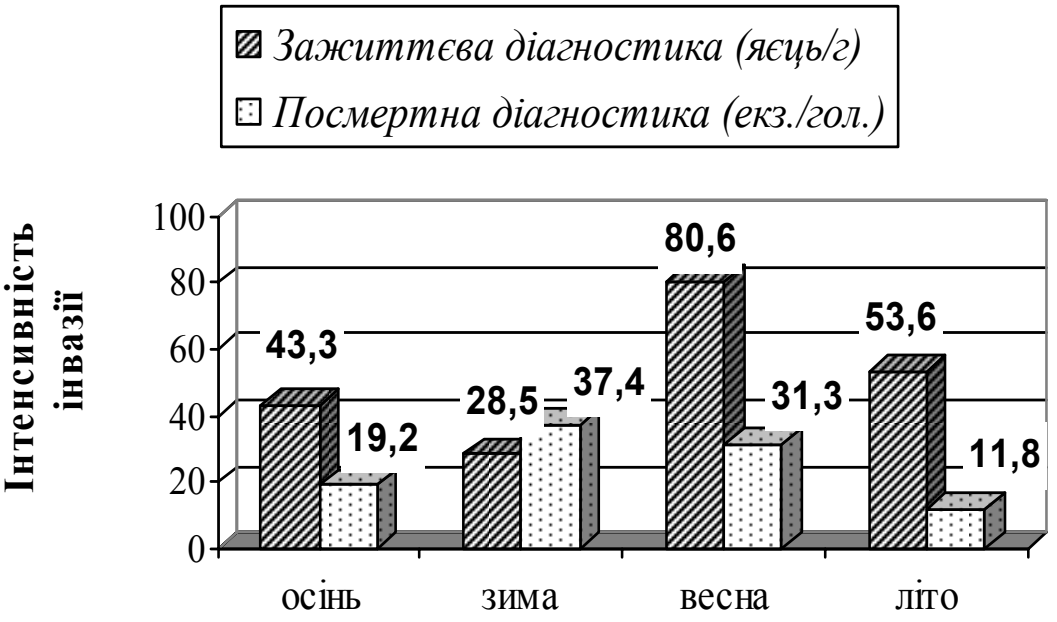

Рис. 2. Показники інтенсивності капіляріозної інвазї̈ залежсо від пори року 


\section{ВЕТЕРИНАРНА МЕДИЦИНА}

Восени показники інвазованості птиці знижувалися (EI - 21,82 \%, II - 43,33 $\pm 5,95$ ЯГП) і досягали мінімальних значень узимку (EI - 12,73 \%, II - 28,57 $\pm 5,95$ ЯГП). Таку сезонну динаміку можна пояснити біологічною особливістю капілярій, яка характеризується максимальною яйцепродукцією самок нематод у зв'язку зі сприйнятливими умовами зовнішнього середовища. У теплий період року відбувається швидкий ембріогенез, реєструється висока збереженість яєць у зовнішньому середовищі, що сприяє подальшому зараженню сприйнятливих хазяїв i збереженню виду вцілому.

За результатами гельмінтологічних розтинів кишечників гусей встановлено, що екстенсивність інвазії впродовж року вища (до 72,22 \%), а інтенсивність інвазії нижча $(37,48 \pm 1,70$ екз./гол), ніж за показниками копроскопічних досліджень $(54,55 \%$ та 80,67士5,29 ЯГП відповідно). У сезонному аспекті пік капіляріозної інвазії припадав на зимово-весняний період року (ЕI до $72,22 \%$ за II - 37,48 $\pm 1,70$ екз./гол.) зі спадом показників інвазованості птиці влітку (39,62 \%, $11,86 \pm 1,53$ екз./гол.). У подальшому в осінній період року встановлювали незначне підвищення ЕI до 58,95 \%, а II до 19,21 $\pm 1,14$ екз./гол. Такі особливості сезонної динаміки, на нашу думку, можна пояснити тим, що у зимовий період року самки капілярій, концентруючись у кишечнику

\section{БІБЛІОГРАФІЯ}

1. Богач M. В. Ехінуріоз домашніх гусей / М. В. Богач, Л. С. Бездєтко, В. П. Монастирлі // Ветеринарна медицина : міжвід. темат. наук. зб. - X., 2008. - №91. - C. 60-62.

2. Гадючко О. Т. Сучасний генофонд вітчизняного і зарубіжного походження та перспективи його використання в Україні / О. Т. Гадючко, О. О. Катеринич, В. П. Коваленко // Птахівництво : міжвід. темат. наук. зб. - Х., 2008. - Вип. 62. - С. 59-82.

3. Кирилюк О. Ф. Розвиток ринку продукції птахівництва / О. Ф. Кирилюк // Вісник аграрної науки. - 2012. - №8 (12). - С. 80-82.

4. Ломако Д. В. Технологія інкубації гусячих яєць в умовах Миргородського приватного орендного сільськогосподарського інкубаторноптахівничого підприємства / Д. В. Ломако // Вісник Полтавської державної аграрної академії. 2015. - №4. - С. 44-46.

5. Маржсхова Л. М. Паразитофауна домашних уток Северного Кавказа и ее эколого-эпизоотологическая характеристика / Л. М. Маржохова, А. А. Жигунова // Российский паразитологический журнал. - 2008. - №1. - С. 8-18. птиці, перестають відкладати яйця, оскільки створюються несприятливі фактори для їх розвитку. В подальшому, у літній період року відповідно до життєвого циклу капілярій відбувається відходження нематод 3 організму птиці, тому їх кількість зменшується.

Отже, капіляріоз гусей на території Полтавської області перебігає 3 вираженою сезонною динамікою, яка пов'язана з біологічними особливостями нематод і кліматичними умовами регіону.

\section{Висновки:}

1. Встановлено, що в умовах Полтавської області капіляріоз гусей перебігає 3 вираженою сезонною динамікою.

2. За результатами копроскопічних досліджень гусей максимальну ураженість капіляріями спостерігали у весняно-літній період року ЕI сягала $54,55 \%$, за II до 80,67 $\pm 5,29$ яєць/г.

3. За результатами гельмінтологічного розтину кишечників гусей пік капіляріозної інвазії встановлено у зимово-весняний період року, ЕI

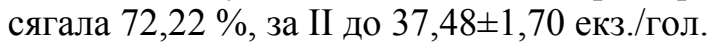

Перспективи подальшої роботи в цзьому напрямі. Перспективами подальших досліджень $є$ визначення ефективності сучасних антигельмінтних препаратів за капіляріозу гусей, а також економічне обгрунтування доцільності їх застосування.

6. Маршалкіна Т. В. Епізоотологічний моніторинг гельмінтозних та протозойних хвороб свійської птиці у промислових, фермерських та присадибних господарствах степової зони України / Т. В. Маршалкіна, Г. В. Заікіна, Г. О. Крива // Бюлетень Інституту сільського господарства степової зони. - 2013. - №5. - С. 157-161.

7. Приходько Ю. О. Система інтегрованого захисту тварин від паразитів в Україні / Ю. О. Приходько // Здоров'я тварин і ліки. 2013. - №12 (145). - С. 18-19.

8. Ревзина Р. В. Гельминтофауна гусей Брянской области / Р.В. Ревзина // Труды ВИГИС им. К. И. Скрябина. - М., 2002. - Т. 38. - С. 237-245.

9. Barus $V$. Influence of breeding technology of helminth fauna of geese (Anser anser $f$. domestica) / V. Barus, A. Mikoбsek, J. Busta // Folia Parasitologica. - 1977. - Vol. 24. - P. 305-314.

10. Gicik $Y$. The Prevalence of Helminths in the Alimentary Tract of Geese (Anser anser domesticus) in Kras District, Turkey / Y. Gicik, M. O. Arslan // Veterinary Research Communications. - 2003. Vol. 27. - P. 391-395. 